\title{
VENEZUELA'S NASCENT OIL INDUSTRY AND THE 1932 US TARIFF ON CRUDE OIL IMPORTS, 1927-1935*
}

\author{
BRIAN S. McBETH \\ St Antony's College, Oxford ${ }^{a}$
}

\begin{abstract}
After a brief description of the initial development of Venezuela's crude oil industry, this paper examines the impact the 1932 US tariff on crude oil imports had on the country. The US tariff on crude oil imports stabilised domestic crude oil prices but prevented consumers from benefiting from lower prices in refined petroleum products. The large US international integrated crude oil companies gained from higher crude oil prices for their domestic production while supplying their European markets with mostly cheap crude oil from their newly developed Venezuelan oilfields. The tariff increased the Venezuelan oil industry's vulnerability to international events because it narrowed the competitive edge it had over domestic US crude oil production. Consequently, the Gómez dictatorship in Venezuela at the time became more dependent on the oil companies operating in the country since they could reduce production considerably, or even leave the country as quickly as they entered with a negative impact on government revenues.
\end{abstract}

Keywords: international relations, natural resources, petroleum, tariffs, Venezuela, interwar years

JEL Classification: N46, N56

* Received 01/31/2009. Accepted 08/17/2009. The author is grateful to the anonymous reviewers and editors for their insightful comments that substantially improved this article. All the original Spanish quotations were translated by the author.

a Senior Common Room Member. brian@mcbeth.demon.co.uk. 


\section{RESUMEN}

Después de una breve explicación del desarrollo inicial de la industria petrolera venezolana, el artículo examina el impacto de la tarifa a las importaciones de petróleo promulgada en los EE.UU. en 1932 sobre Venezuela. La tarifa americana a las importaciones de petróleo crudo estabilizó los precios de petróleo que habían llegado a un nivel muy bajo. Esto impidió que los consumidores se beneficiaran de precios bajos en productos de petróleo refinado. Las grandes petroleras integradas americanas que suministraban petróleo al mercado doméstico e internacional ahora recibían precios relativamente altos para su producción doméstica mientras abastecían los mercados europeos en la mayoría con petróleo barato de sus nuevos yacimientos venezolanos. La tarifa aumentó la vulnerabilidad de Venezuela a los eventos internacionales porque se redujo la ventaja comparativa que tenía con la producción de petróleo de los EE.UU. En consecuencia, la dictadura gomecista se volvió más dependiente de las compañías petroleras extranjeras en el país, ya que éstas podrían reducir considerablemente la producción o incluso abandonar el país tan pronto como habían entrado con un impacto negativo en los ingresos fiscales del gobierno.

Palabras clave: relaciones internacionales, recursos naturales, petróleo, aranceles, Venezuela, periodo de entreguerras

\section{INTRODUCTION}

In the 1920s, the Venezuelan oil industry increased its production rapidly becoming in 1928 the second largest producer in the world after the US. At the end of the 1920s and early 1930s, crude oil prices in the US collapsed by almost 50 per cent following an increase in domestic crude oil production of 150 per cent together with a considerable rise in Venezuelan crude oil imports. This led to calls for domestic crude oil production to be shut-in as well as curtailing crude oil imports. The political decision to reduce production of a resource benefits producers rather than consumers as demonstrated by, among others, Adam Smith (Smith, 1981), Frederic Bastiat (Bastiat, 1996), David Ricardo (Ricardo, 1992), Jagish Bhagwati (Bhagwati, 1988) and Patrick Messerlin (Messerlin, 2001). Such a situation usually develops because a relatively small group of companies can organise themselves around a particular issue. Moreover, when a government intervenes in favour of an interest group it reduces the efficiency and benefits of a free market.

The political decision to manipulate a market leads to inefficiencies as well as sending false signals in the allocation of resources where greater value is added. This is the case when a tariff or an import quota is imposed as it benefits specific producers at the expense of consumers because cheap 
imports are unavailable. There are also hidden costs associated with trade protection such as the inefficient use of capital and labour, higher consumer prices, fewer incentives to increase productivity, less innovation and improvements in quality, as well as the expense of lobbying for import restrictions. These costs are difficult for ordinary citizens to assess and tend not to influence government policy. Industries that are perceived to be harmed by free trade tend to favour restriction of foreign competition and organise themselves in a way that may influence political decisions on the issue. It is relatively easy for the general population of a country to believe that foreign competition is harmful to the domestic crude oil industry because it may directly increase unemployment. In addition, the votes of those made redundant by foreign imports can also assume greater political significance and hence it is understandable why some politicians favour protectionism.

Many of these problems were present in the late 1920s and early 1930s in the US when a few large oil companies with producing assets in both the US and Venezuela started importing foreign crude oil. This paper shows that the 1932 US tariff on foreign crude oil established a base for crude oil prices that served to maximise returns on capital employed for certain oil companies at the expense of consumers. Moreover, companies with assets in both the US and Venezuela gained the most by diverting their foreign supplies to Europe, while maximising their returns in the US. This also meant that crude oil production in Venezuela did not decline as much as was anticipated at the time. Finally, the post-tariff experience revealed to the Venezuelan government its vulnerability to external change, its lack of control over the development of the industry, and its dependence on a continuous increase of crude oil revenues to balance its budget.

\section{THE VENEZUELAN OIL INDUSTRY}

The development of the Venezuelan oil industry took place during the dictatorship of General Juan Vicente Gómez (1908-1935) and is linked mainly with the Royal/Dutch Shell Group (Shell), Standard Oil Co. (Indiana) (Standard Indiana), Gulf Oil Corp. (Gulf Oil), and the British Controlled Oilfields Ltd., which in 1933 produced 99.2 per cent (Table 1) of the country's total crude oil production of 323,839 barrels of crude oil per day (bopd) (McBeth, 1985: 87). The initial development of the oil industry took place in Zulia and Falcón States and later moved eastwards to Monagas State.

Following the discovery of Barroso No. 2 in December 1922 in Zulia State, a large number of wells were drilled during the 1920s, reaching a peak of 615 in 1929 (Figure 1), with the five largest companies completing almost 500 wells by the end of 1926 . The general success rate at finding oil of 89.4 per cent was very high, rising to 100 per cent in fields such as Mene Grande. 
TABLE 1

AVERAGE CRUDE PRODUCTION FOR VARIOUS OIL COMPANIES, 1927 \& 1933 (BOPD)

\begin{tabular}{|l|c|c|c|c|}
\hline \multicolumn{1}{|c|}{ Company } & $\mathbf{1 9 2 7}$ & $\begin{array}{c}\text { Total Prod. } \\
\mathbf{( \% )}\end{array}$ & $\mathbf{1 9 3 3}$ & $\begin{array}{c}\text { Total Prod. } \\
(\mathbf{\%})\end{array}$ \\
\hline Shell Group & 78,874 & 47.7 & 166,005 & 51.2 \\
\hline Venezuelan Oil Concessions Ltd. & 59,774 & 36.1 & 89,762 & 27.7 \\
\hline \multicolumn{1}{|c|}{ Caribbean Petroleum Co. } & 18,847 & 11.4 & 34,702 & 10.7 \\
\hline \multicolumn{1}{|c|}{ Colon Development Co. } & 253,000 & 0.2 & 41,541 & 12.8 \\
\hline Venezuelan Gulf Oil Co. & 22,416 & 13.5 & 35,656 & 11.0 \\
\hline Lago Petroleum Corp. & 26,501 & 16.0 & 98,794 & 30.5 \\
\hline British Controlled Oilfields Ltd. & 6,736 & 4.1 & 20,940 & 6.5 \\
\hline Total & $\mathbf{1 3 4 , 5 2 7}$ & $\mathbf{8 1 . 3}$ & $\mathbf{3 2 1 , 3 9 5}$ & $\mathbf{9 9 . 2}$ \\
\hline
\end{tabular}

Source: Adapted from FO 371/12063 Memorandum on Oil Production in Venezuela, 19.8.1927 \& Oil News «Venezuelan Drilling and Production in 1933», 1.2.35.

The production of crude oil per active well between 1922 and 1935 averaged 72,769 barrels (Figure 2), which was much higher than in any region of the US, which between 1933 and 1935 averaged 2,804 barrels per productive well (American Petroleum Institute, 1939: 65).

FIGURE 1

WELLS DRILLED IN VENEZUELA

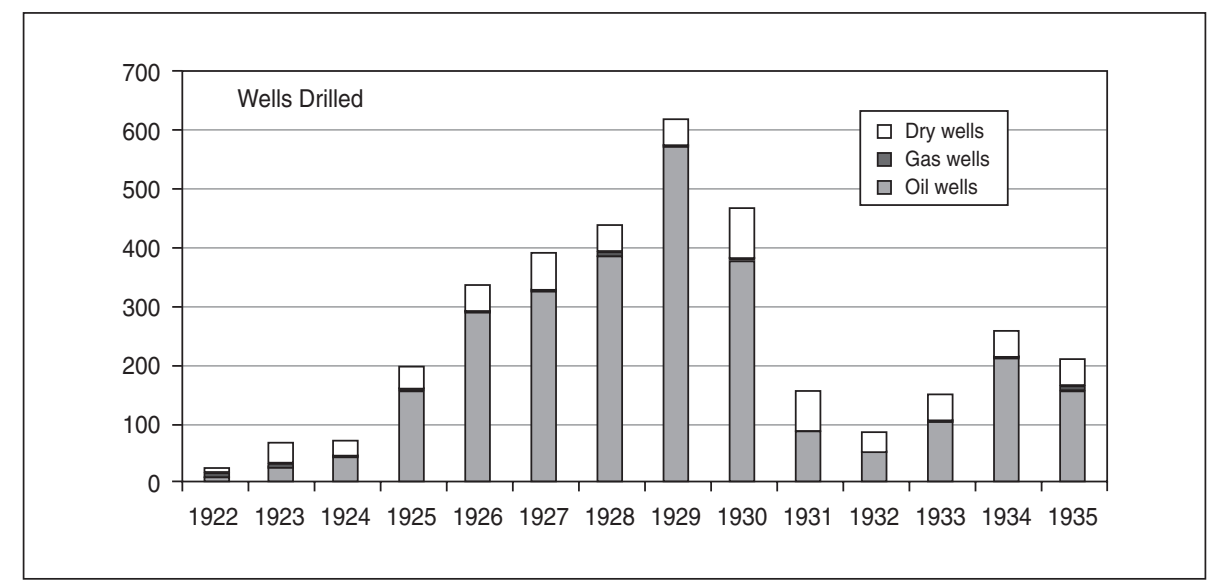

Source: Adapted, Venezuela, Ministry of Mines and Hydrocarbons 1966: 1. 
FIGURE 2

CRUDE OIL PRODUCTION PER ACTIVE WELL (BARRELS)

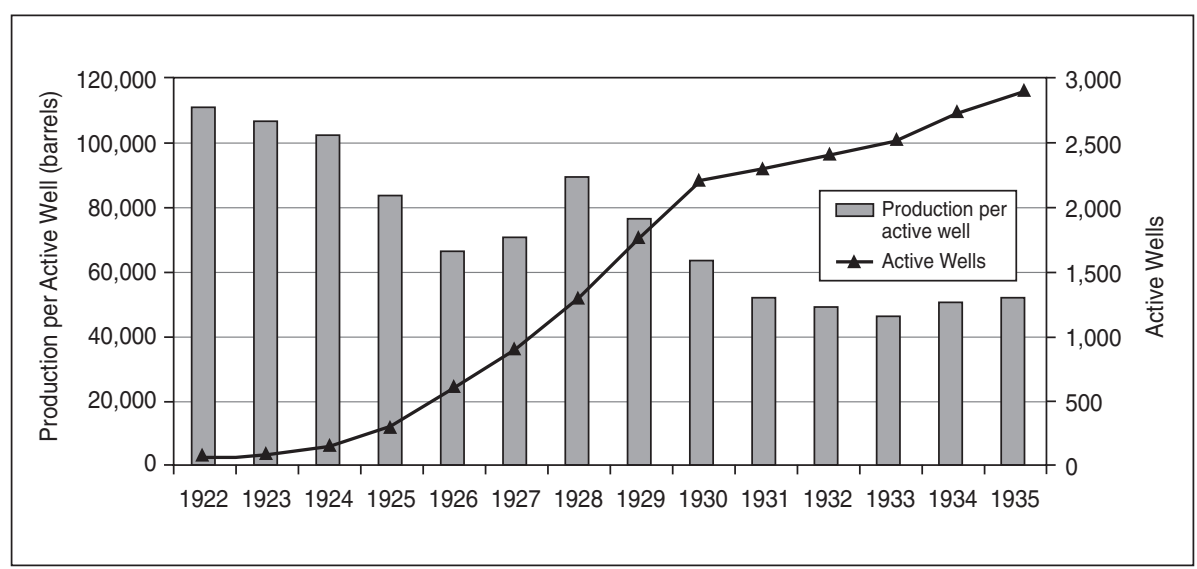

Source: Calculated from Venezuela, Ministry of Mines and Hydrocarbons, Directorate General 1966: p. 1.

With such a large increase in the number of highly productive active wells, within six years of the Barroso 2 discovery Venezuela became the world's second largest oil producer after the US, producing 289,500 bopd (Table 2), equivalent to 8 per cent of world oil production (Figure 3), and ahead of the USSR with 233,394 bopd.

TABLE 2

US DOMINANCE OF WORLD CRUDE OIL PRODUCTION ( M BOPD)

\begin{tabular}{|l|r|r|r|c|}
\hline \multirow{2}{*}{ Country } & \multicolumn{2}{|c|}{1918} & \multicolumn{2}{c|}{1928} \\
\cline { 2 - 5 } & Production & \% of Total & Production & \% of Total \\
\hline USA & 975,145 & 70.7 & $2,463,044$ & 68.0 \\
\hline USSR & 74,433 & 5.4 & 233,394 & 6.4 \\
\hline Venezuela & 878,000 & 0.1 & 289,500 & 8.0 \\
\hline Mexico & 174,871 & 12.7 & 137,024 & 3.8 \\
\hline Rest of World & 154,166 & 11.2 & 496,639 & 13.7 \\
\hline Total & $\mathbf{1 , 3 7 9 , 4 9 3}$ & $\mathbf{1 0 0 . 0}$ & $\mathbf{3 , 6 1 9 , 6 0 1}$ & $\mathbf{1 0 0 . 0}$ \\
\hline
\end{tabular}

Source: Adapted, Venezuela, Ministerio de Minas e Hidrocarburos, Dirección General: 1964: 142. 
FIGURE 3

VENEZUELAN CRUDE OIL PRODUCTION PRODUCTION \& PERCENTAGE OF WORLD PRODUCTION, 1917-1935

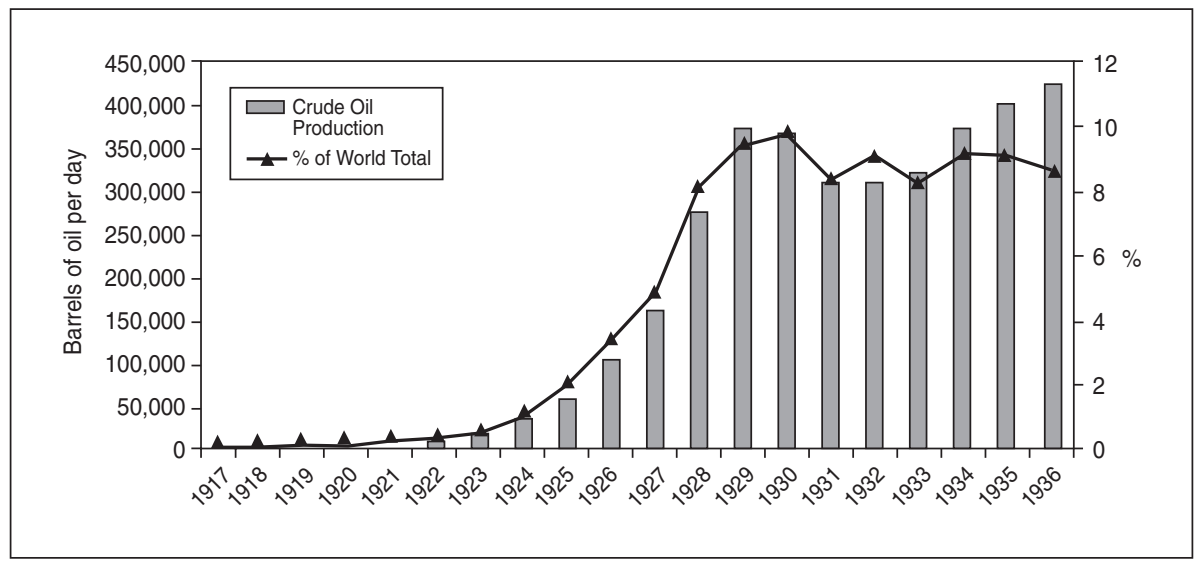

Such a large increase in Venezuelan production meant that the country took a greater share of the world's market. In 1929-30, Venezuelan crude oil and petroleum products accounted for just over 70 per cent of total crude oil and refined products imported by the US (Table 3 ).

TABLE 3

US IMPORTS OF PETROLEUM AND ITS LIQUID REFINED PRODUCTS BY COUNTRIES OF SHIPMENT. YEARS 1929-30 COMBINED (\%)

\begin{tabular}{|l|c|c|c|}
\hline Country of Shipment & $\begin{array}{c}\text { Total Crude Petroleum } \\
\text { \& Refined Products }\end{array}$ & $\begin{array}{c}\text { Crude } \\
\text { Petroleum }\end{array}$ & $\begin{array}{c}\text { Refined Petroleum } \\
\text { Products }\end{array}$ \\
\hline Dutch West Indies* & 42.6 & 18.4 & 89.3 \\
\hline Venezuela & 28.0 & 42.4 & 0.4 \\
\hline Sub-Total & 70.6 & 60.8 & 89.7 \\
\hline \multicolumn{4}{|l|}{} \\
\hline Colombia & 12.5 & 19.0 & - \\
\hline Mexico & 12.5 & 16.1 & 5.5 \\
\hline Trinidad & 1.3 & 0.3 & - \\
\hline Peru & 1.3 & 1.9 & - \\
\hline Ecuador & 1.2 & 1.8 & 1.7 \\
\hline Others & 0.6 & 0.1 & - \\
\hline
\end{tabular}

* The Dutch West Indies only refined Venezuelan crude.

Source: US House of Representative 1934: Adapted, Table 3, p.13. 


\section{ECONOMIC IMPACT OF THE OIL INDUSTRY}

The increase in crude oil production meant that towards the end of the Gómez dictatorship oil taxes accounted for just over a quarter of total government revenue. In addition, considerable indirect taxes, such as customs receipts generated by the oil industry, also accrued to the Treasury. The government's oil taxes accounted for around 14 per cent of the value of the crude oil produced at the end of the Gómez period (Table 4).

TABLE 4

GOVERNMENT REVENUE, OIL TAXES \& VALUE OF CRUDE OIL, 1927-1935

(Bs. Million)

\begin{tabular}{|c|c|c|c|c|c|}
\hline Year & $\begin{array}{c}\text { Government } \\
\text { Revenue }\end{array}$ & Oil Taxes & $\begin{array}{c}\text { Oil Taxes as } \\
\text { a \% of Total } \\
\text { Taxes }\end{array}$ & $\begin{array}{c}\text { Value of } \\
\text { Crude Oil } \\
\text { Produced }\end{array}$ & $\begin{array}{c}\text { Oil Taxes } \\
\text { as a \% of } \\
\text { the Value of } \\
\text { Crude Oil }\end{array}$ \\
\hline 1927 & 182.1 & 21.4 & 11.8 & 338.4 & 6.3 \\
\hline 1928 & 187.7 & 46.2 & 24.7 & 563.6 & 8.2 \\
\hline 1929 & 230.4 & 50.5 & 21.9 & 829.3 & 6.1 \\
\hline 1930 & 255.4 & 47.3 & 18.5 & 864.0 & 5.5 \\
\hline 1931 & 210.3 & 47.0 & 22.3 & 568.1 & 8.3 \\
\hline 1932 & 185.1 & 45.2 & 24.4 & 612.2 & 7.4 \\
\hline 1933 & 171.9 & 43.5 & 25.3 & 284.3 & 15.7 \\
\hline 1934 & 171.8 & 46.7 & 27.2 & 380.0 & 13.7 \\
\hline 1935 & 203.0 & 51.9 & 25.6 & 428.1 & 13.8 \\
\hline
\end{tabular}

Source: Adapted, Carrillo Batalla 2003, Cuadro 6, p.325 \& Cuadro 6.2, p. 612.

Within a very short period the oil industry became the largest economic sector in the economy reaching almost 40 per cent of Gross Domestic Product in 1934 (Table 5). The impact of the Great Depression on Maracaibo was swift and severe. The region experienced a decline in economic activity almost simultaneously with the fall in oil and coffee exports. The level of net capital investment in the crude oil industry fell significantly as the global economic depression took effect as well as the uncertainty over the effect of the 1932 US tariff on crude oil imports, declining from US $\$ 331$ million in 1929 to US $\$ 82$ million in 1932. The number of oil workers also fell from a high of 27,221 in 1929 to 8,332 in 1932 (Table 6). 
TABLE 5

GROSS DOMESTIC PRODUCT BY SECTORS, 1927 - 1935 (BOLIVARS M)

\begin{tabular}{|c|c|c|c|c|c|c|c|c|c|}
\hline Year & $\begin{array}{c}\text { Agri- } \\
\text { culture }\end{array}$ & $\begin{array}{c}\% \text { of } \\
\text { Total }\end{array}$ & $\begin{array}{c}\text { Hydro- } \\
\text { carbons }\end{array}$ & $\begin{array}{c}\% \text { of } \\
\text { Total }\end{array}$ & $\begin{array}{c}\text { Indus- } \\
\text { try }\end{array}$ & $\begin{array}{c}\text { \% of } \\
\text { Total }\end{array}$ & $\begin{array}{c}\text { Com- } \\
\text { merce \& } \\
\text { Services }\end{array}$ & $\begin{array}{c}\text { \% of } \\
\text { Total }\end{array}$ & Total \\
\hline 1927 & 259.0 & 32.4 & 141.1 & 17.6 & 140.9 & 17.6 & 259.4 & 32.4 & 800.4 \\
\hline 1928 & 255.4 & 26.1 & 237.8 & 24.3 & 164.4 & 16.8 & 319.5 & 32.7 & 977.1 \\
\hline 1929 & 283.6 & 23.9 & 341.1 & 28.7 & 193.5 & 16.3 & 370.3 & 31.2 & $1,188.5$ \\
\hline 1930 & 276.1 & 21.4 & 419.1 & 32.5 & 207.6 & 16.1 & 386.3 & 30.0 & $1,289.1$ \\
\hline 1931 & 291.8 & 27.2 & 386.2 & 35.9 & 173.1 & 16.1 & 223.5 & 20.8 & $1,074.6$ \\
\hline 1932 & 297.1 & 24.7 & 413.2 & 34.4 & 175.6 & 14.6 & 315.8 & 26.3 & $1,201.7$ \\
\hline 1933 & 295.4 & 22.7 & 488.1 & 37.6 & 185.2 & 14.3 & 329.8 & 25.4 & $1,298.5$ \\
\hline 1934 & 312.7 & 21.1 & 575.0 & 38.8 & 214.8 & 14.5 & 380.1 & 25.6 & $1,482.6$ \\
\hline 1935 & 328.7 & 18.8 & 651.0 & 37.3 & 274.6 & 15.7 & 491.8 & 28.2 & $1,746.1$ \\
\hline
\end{tabular}

Source: Adapted, Rangel 1970: Table 21, 149.

TABLE 6

CAPITAL ACCUMULATION IN THE OIL SECTOR AND NUMBER OF OIL WORKERS, 1922-1935

\begin{tabular}{|c|c|c|c|}
\hline Year & $\begin{array}{c}\text { Net Annual Capital } \\
\text { Invested in the Crude } \\
\text { Oil Sector (US\$m) }\end{array}$ & $\begin{array}{c}\text { Capital Accumulation } \\
\text { in the Oil Sector } \\
\text { (US } \mathbf{\$} \text { ) }\end{array}$ & $\begin{array}{c}\text { Number } \\
\text { of } \\
\text { Oil Workers }\end{array}$ \\
\hline 1927 & 319 & 890 & 21,174 \\
\hline 1928 & 233 & 1,072 & 21,240 \\
\hline 1929 & 331 & 1,339 & 27,221 \\
\hline 1930 & 189 & 1,417 & 21,009 \\
\hline 1931 & 79 & 1,373 & 12,064 \\
\hline 1932 & 82 & 1,249 & 8,832 \\
\hline 1933 & 86 & 1,131 & 10,855 \\
\hline 1934 & 74 & 934 & 11,546 \\
\hline 1935 & 85 & 921 & 12,333 \\
\hline
\end{tabular}

Source: Adapted from Baptista 1997: Cuadro Inversión Bruta Total en Petróleo, 1920-1995, p.212 \& «Capital Neto Total Sector Petrolero, 1920-1995», p.248 and Rangel 1970: Cuadro 34, p. 209. 


\section{DECLINING CRUDE OIL RESERVES}

The increased activity in the Venezuelan oil industry was associated with a large rise in foreign capital, especially from the US, which during the 1920s displaced British capital into second place. In 1914, US investments in the country amounted to $\$ 8$ million, rising to $\$ 247,238,000$ in 1930 compared with total British investments of US $\$ 124,667,690$ (see Dunn, 1926, and Osborne, 1912) ${ }^{1}$ in the same year. The large increase in US foreign crude oil investments was partly due to concerns at the end of World War I that America was running out of hydrocarbon reserves leading to a decline in its crude oil production, which accounted for approximately 70 per cent of world crude oil production (Table 2). In 1919, David White, Chief Geologist of the US Geological Survey, estimated that US petroleum reserves were 6.74 billion barrels and predicted that by 1925 «the country would be dependent upon foreign oil fields to the extent of 150,000,000 barrels each year» (US Senate, 1946a: 7). Six years later, the State Department's Economic Adviser, echoing White's statements, advised that «the importance of the Venezuelan oil fields as a supply for the ever increasing demand for petroleum products in this country cannot be overlooked - not to mention the almost certain decline in domestic production that will come» ${ }^{2}$. The Federal Oil Conservation Board (FOCB) in its September 6, 1926 report urged US oil companies to "seek production abroad ${ }^{3}$ by acquiring large undrilled geological petroleum structures discovered in Latin America «not only as a source of future supply, but of a supply under control of our citizens» ${ }^{4}$. The rise in crude oil consumption in the US was led directly by a large increase in car ownership, which rose from 1.7 million cars in 1919 to 4.6 million cars in 1929. Moreover, the American economy grew substantially during the 1920s, with manufacturing activity rising by 23.5 per cent between 1923 and 1929 (Smiley, 2002: 4).

During this period the US oil companies shifted their geographical mix of assets. In 1919, US crude oil companies held 28 per cent of their capital employed in North America, compared with 23 per cent in Europe and South East Asia and 17 per cent in South America. During the next 20 years there was a significant move away from the US, with the companies in 1939 holding 42 per cent of their assets in South America and 29 per cent in Europe compared with 12 per cent in North America (US Senate, 1946: 158). In spite of the strong interest in exploration outside the US, the oil sector was only the fourth largest recipient of direct US foreign investments in Latin

1 Also Latin American World (1933: 51).

2 US Government, Records of the Department of State relating to the Internal Affairs of Venezuela (DS) 831.6363/284 Department of State, Office of the Economic Adviser, «Petroleum Situation in Venezuela», Washington, 2.9.25.

3 Ibid.

4 Ibid. 
America in 1929, rising to second place in 1943 (Rippy, 1958: 43). The large foreign investments made by US oil companies in exploration and production during this period were concentrated mainly in Venezuela, which was the largest single recipient of direct US oil investments between 1929 and 1940 (Table 7).

TABLE 7

AMERICAN DIRECT OIL INVESTMENTS IN FOREIGN COUNTRIES, 1929-1940

\begin{tabular}{|l|c|c|c|c|c|c|}
\hline \multirow{2}{*}{ Country } & \multicolumn{3}{|c|}{$\begin{array}{c}\text { \% of Total US Oil } \\
\text { Investments }\end{array}$} & \multicolumn{3}{c|}{$\begin{array}{c}\text { Oil Investments as a \% of } \\
\text { Total US Investments in } \\
\text { the Country }\end{array}$} \\
\cline { 2 - 8 } & $\mathbf{1 9 2 9}$ & $\mathbf{1 9 3 6}$ & $\mathbf{1 9 4 0}$ & $\mathbf{1 9 2 9}$ & $\mathbf{1 9 3 6}$ & $\mathbf{1 9 4 0}$ \\
\hline Venezuela & 20.2 & 16.3 & 19.5 & 97.3 & 93.6 & 95.2 \\
\hline Mexico & 18.5 & 6.4 & 3.3 & 30.2 & 14.4 & 11.7 \\
\hline Colombia & 5.0 & 5.5 & 5.9 & 45.0 & 54.5 & 67.3 \\
\hline $\begin{array}{l}\text { Saudi Arabia, Bahrain \& } \\
\text { Iran }\end{array}$ & 0.0 & 1.6 & 4.4 & 0.0 & 98.2 & 98.3 \\
\hline
\end{tabular}

Source: US Senate 1946: 158.

\section{OVERSUPPLY OF CRUDE OIL}

The problem of crude oil overproduction in the US was already apparent in early 1923, largely owing to the prolific new oilfields that came on-stream in Arkansas and California, accounting for a third of the country's production of 1.65 million bopd ${ }^{5}$. The supply of crude oil between 1920 and 1923 increased by 134 per cent whereas crude oil consumption rose by 41.5 per cent during the same period. The acute oversupply of crude oil together with the 1924 Teapot Dome scandal (see Bates, 1963; Nash, 1968, and Noggle, 1965) led to greater government control of the industry to conserve crude oil by ensuring that supply matched demand. On December 19, 1924 President Calvin Coolidge created the FOCB consisting of John W. Weeks, Secretary of War, Curtis Dwight Wilbur, Secretary of the Navy, Hubert Work, Secretary of the Interior and Herbert Clark Hoover, Secretary of Commerce, to recommend a national policy for the oil industry because of the need to conserve crude oil reserves for future consumption. The FOCB could not restrict production but recommended in 1926 that the oil-producing states should co-operate to pro-ration production to ensure that oil was not wasted. The

5 UK National Archives, Cabinet Office, Foreign Office, General Correspondence, Political (FO) 371/8493 Standard Daily Trade Service, 2.2.23. 
oversupply of crude oil became more acute with the discovery of the flush oilfields of the Seminole pool in Oklahoma in July of the same year, with crude oil prices falling significantly.

In May 1927, Walter Clark Teagle, President of Standard Oil Co. (New Jersey) (Exxon), and a number of other leading oilmen in New York agreed to restrict the number of wells drilled in the Greater Seminole field. This decision was further strengthened when on August 9, 1927 the Oklahoma Corporation Commission, under a 1915 law, set the maximum production level for the oilfield and ordered it to be prorated among producers, and was later followed by state-wide prorationing on September 8, 1928 (see Redfield, 1942). Soon afterwards, California and Texas curtailed production by voluntary agreement, but the discovery of two large oilfields in the two states drove prices down even further. It became clear that «voluntary restrictions on drilling and output along with private prorationing by the pipelines were inadequate for checking rising production»(Engler, 1961: 137) even though the Federal Courts in certain instances tried to enforce some of the prorationing agreements (see Rostow, 1948).

\section{COMPETITION AND SYNTHETIC OIL}

In the mid 1920s, a time when large US oil reserves were being discovered and Venezuelan crude oil production was rising rapidly, the industry was further threatened by the development of synthetic crude oil in Germany. In 1925, I G Farbenindustrie (I G Farben), the giant German chemical company, announced at the World Coal Conference in Pittsburgh that it held Professor Bergius' patent to manufacture synthetic crude oil from coal. According to Patrick A. Gibson, US Assistant Attorney General in 1942, the "process was capable of converting coal into gasoline or any other oil products» (US Senate, 1942: 3337) ${ }^{6}$. The international oil companies, faced with such a threat, took active steps to lessen its impact on the market. After a number of meetings between Exxon, Shell and I G Farben during 1926-28 an agreement was reached, with the oil companies staying out of the chemical market and the German chemical company not manufacturing synthetic crude oil (see US Senate, 1942, and US Senate, 1945). The experience with I G Farben confirmed to Sir Henri Deterding, who headed Shell, his view of the need to maintain high prices by restricting production (Deterding, 1934: 31). On July 30, 1928 the American Petroleum Institute (API) organised a conference to control production from prolific foreign oilfields. This had an immediate impact in Venezuela, with a decline in the number of competitive wells drilled, commonly known as

${ }^{6}$ Testimony of Patrick A. Gibson, Assistant Attorney General, Antitrust Division, Department of Justice'. 
a «line fight», in Zulia State ${ }^{7}$. A few months later, on September 17, 1928 Teagle, Deterding, and Sir John Cadman, Chairman of the Anglo Persian Oil Co. (BP) met at Achnacarry Castle in Scotland and signed the Pool Association Agreement, usually known as the "As Is» or "Achnacarry Agreement», which called on the three companies to pool their resources to simplify their operations (see US Tariff Commission, 1952). This was the first of many accords reached by the companies, which were subsequently dissolved during World War II (see US Tariff Commission, 1952, and McBeth, 1985).

In February 1929 a Committee on World Production and Consumption of Petroleum and its Products (CWPCP), representing the views of $80 \mathrm{com}$ panies operating in the US and South America, was established. A few weeks later, on March 15, 1929, the Committee's first control plan was unveiled at a meeting held in Houston, Texas, attended by Federal and State government officials, as well as industry representatives. The meeting recommended that crude oil production in 1928 "should be considered as peak requirements for 1929 and subsequent years, proposing in effect that average production in future years be held to the 1928 level» (US Tariff Commission, 1952: 212). The Committee's recommendation was designed to control production in the US domestic oil industry, while the members of the 1928 Pool Division would control the rest of the world. The US oil market and export trade were outside the scope of the agreement because of US anti-trust laws and it was reasoned that US petroleum imports would decline if foreign crude oil was curtailed.

On March 27, 1929 the API and the US oil companies that were also foreign oil producers fully endorsed the recommendations of the CWPCP, which were submitted seven days later to the FOCB, headed by Interior Secretary Ray Lyman Wilbur ${ }^{8}$. The FOCB, however, did not have the legal authority to regulate drilling or production because that rested solely with the state governments. Wilbur then suggested a renewal of discussions between the oil states and the oilmen to explore the establishment of an inter-state compact «to which the Federal government, through Congressional action, would be a party» (US Tariff Commission, 1952: 213). Soon after this, on June 20, 1929 Mark Lawrence Requa, acting on behalf of President Herbert Hoover, convened a conference at the Broadmoor Hotel in Colorado Springs between the representatives of the oil industry and seven oil-producing state Governors (Texas, California, Oklahoma, Kansas, Wyoming, New Mexico, and Colorado), together with representatives of the Governors of Arkansas, Louisiana, Montana and Utah. Edwin Benjamin Reeser, head of Barnsdall Corp. and President of the API, led the 21 representatives of the oil industry,

\footnotetext{
7 Alexander K. Sloan «Agreement between the Lago Petroleum Corporation, The Venezuelan Gulf Oil Company and The Venezuelan Oil Concessions», DS 831.6363/355, Maracaibo, 9.4.27.

8 Curtis Dwight's brother.
} 
including Ralph Clinton Holmes of Texas Corp., Kenneth Raleigh Kingsbury of Standard Oil Co. (California), Teagle of Exxon, Robert Giffen Stewart of the Pan-American Petroleum and Transport Co. (PAPT) and Albert Edward Watts of Sinclair Oil Corp. At the conference, Wilbur repeated the conservation policies advocated by FOCB, adding that if he was the country's landlord «I would see that we used as much imported oil and let the other fellow waste his reserves» (US Senate, 1931a: 51) ${ }^{9}$. At the meeting, Dr Otis Smith, Director of the US Geological Survey, reiterated his belief that at current rates of consumption the US only had ten years of crude oil reserves left. In addition, the large rise in Venezuelan crude oil and product exports to the US did not go unnoticed by the domestic crude oil producers. The government then proposed an inter-state compact between the oil-producing states to conserve domestic crude oil supplies, leaving foreign crude oil to meet any additional increase in demand. On July 25, 1929 the Federal Trade Commission introduced a Code of Fair Practices that applied to the refining of crude oil and the marketing of petroleum products, but did not address the crude oil oversupply issue for which Venezuela was increasingly blamed (US House of Representatives, 1932: Table 3, 13).

The Code met with stiff opposition from the large and vocal independent crude oil producers (Independents) who felt that the proposed scheme only benefited foreign crude oil producers and would lead to their eventual demise. Wirt Franklin, President of Franklin Petroleum Co., of Oklahoma City, Oklahoma, was so incensed with the Code that he left the API and, together with 250 Mid-Continent producers, formed the Independent Petroleum Association of America (IPAA). The situation for the Independents was not favourable because the large Mid-Continent producers, such as Standard Indiana and Gulf Oil, accounted for 98 per cent of US crude oil imports and they reduced their Venezuelan crude oil production in 1927 to protect their US interests. It was also clear in 1929 that crude oil from the large oilfields in West Texas and the Gulf region was cheaper to produce than in the Mid-Continent, with the companies using increasing amounts of Venezuelan crude oil to retain their share of the large Atlantic Seaboard market. It was also self-evident to the Independents that, without some artificial barrier imposed on crude oil imports, Venezuelan crude oil would continue to enter the American market because of its cost advantage. Franklin at this stage did not favour an import tariff on foreign crude oil because it would lead to overproduction in the US. Franklin, together with P. Malloy, Sinclair Oil Corp.'s attorney, started instead to work on a plan to restrict the number of foreign oil companies operating in the country and for a quota to be imposed on crude oil imports. Nevertheless, when the General Tariff Act came up for revision in 1929 the Independents pressed for a US\$1/barrel tariff on imported crude oil.

\footnotetext{
9 Statement Wirt Franklin. He read out part of Wilbur's speech.
} 


\section{GOVERNOR'S OIL RELIEF CONFERENCE}

In January 1930, Exxon and Standard Oil Company (New York) cut oil prices further, with the result that the members of the newly formed IPAA travelled to Washington to lobby against the price cuts. Franklin, now heading the IPAA, advocated an import tariff of 50 per cent of the value of imported petroleum products and a straight levy of $\$ 1 /$ barrel for crude oil. At the same time, the governors of the oil-producing states called for an Oil Relief Conference in January 1930. As we have seen, the large international oil companies were co-operating to peg their production to world demand. Exxon, Gulf Oil, Standard Indiana and Shell, which accounted for 95 per cent of total US crude oil imports, closed ranks in order to get the Independents' support for prorationing and agreed to cut imports by 25 per cent and by 50 per cent in Shell's case.

In the early 1930s the companies began to support the US government's efforts to conserve petroleum reserves. R. B. Brown, Secretary of the Governor's Oil Relief Conference, urged the imposition of a foreign import quota because he considered that Venezuela could produce two to three times its current output of around 390,000 bopd. Brown also felt that the large crude oil importers were using foreign crude oil to drive prices down to bankrupt the independent producers and then acquire their assets because «they do not care whether the crude product is 10 cents or 10 dollars a barrel because they use it themselves» (US House of Representatives, 1932: 50) ${ }^{10}$. The large crude oil importing companies did not want their foreign crude oil production undermining the American oil industry but rather, as Sidney A. Swensrud, President of Gulf Oil, later declared on August 4, 1949, to play «a sound and needed role in supplementing our domestic petroleum supply» (US House of Representatives, 1950: 87) ${ }^{11}$.

\section{CRUDE OIL OVERPRODUCTION}

The problem of domestic overproduction still remained, with the FOCB sponsoring in March 1930 a Voluntary Committee on Petroleum Economics, which, together with the Interior Department's Mines Bureau, recommended once again that domestic production be linked to demand and that prorationing be extended beyond individual oilfields to encompass whole states. In Venezuela, Shell proposed reducing its production by the same proportion as the decline in US demand during 1929 and Standard Indiana offered to curtail its production by 9 per cent. According to Robert R. Penn, Vice-President of PAPT, the proposals were not implemented because

10 Statement, R. B. Brown.

11 Testimony by S. A. Swensrud jr. 
«under the Wilson Act they could not agree to restrict foreign imports» (US House of Representatives, 1931: 100) ${ }^{12}$ because it contravened the anti-trust laws.

The burden of curtailing supply through voluntary action was, because of its very nature, impossible to implement equitably. As Watkins points out, the uncertainty of future policy at the time only stimulated the drilling of more wells which usually increased a company's crude oil reserves and hence its allowable output or at least its ability to produce or displace some or all of the oil output " "held in" under proration» (Watkins, 1973: 45). The establishment of an ever larger and more threatening excess potential production meant that the efforts to stabilise markets were defeated. As a result, the government instructed the Tariff Commission to examine the impact of crude oil imports on the domestic crude oil industry. The House Ways and Means Committee and the Senate Finance Committee both investigated the imposition of a tariff on foreign crude oil imports but decided not to impose such a measure, much to Gómez's delight ${ }^{13}$. Instead it investigated the cost of producing crude oil and found in 1930 that Venezuelan crude oil was much cheaper to extract than US domestic oil (see Senate, 1931). Over a three year period from 1927 to 1929, the cost of Venezuelan crude at the point of transfer to ocean tankers, including interest on investment, was on average $\$ 0.65 /$ barrel, with the oil companies using an average transfer value of oil of $\$ 0.69 /$ barrel for the same three years. The sales receipts of the companies showed an average value in their accounts of $\$ 0.85 /$ barrel (see US Senate, 1931).

On February 7, 1931, the US Tariff Commission reported similar results with the average cost of US domestic petroleum delivered to the Atlantic Seaboard for 1927-1930 of $\$ 1.89 /$ barrel (Table 8 ). The costs varied by region from $\$ 0.78 /$ barrel in California, $\$ 0.93 /$ barrel in Texas, $\$ 1.18 /$ barrel in Oklahoma and \$3.00/barrel in New York, giving a nation-wide average of \$1.09/ barrel for 1927-1930. The size of the reserves also had an impact on production costs, so that oilfields that produced more than a million barrels per annum had average production costs of $\$ 1.04 /$ barrel compared to smaller fields at \$1.29/barrel for 1927-30.

The average cost of Maracaibo crude oil delivered at the Eastern Seaboard for the same period was US $\$ 0.87 /$ barrel compared with the average cost for the rest of the world (including Venezuela) of US $\$ 1.15 /$ barrel. The cost of delivering crude oil from Venezuela and the rest of the world to the Atlantic Seaboard was $\$ 1.02 /$ barrel and $\$ 0.74 /$ barrel respectively less than US domestic delivery costs and appeared to give foreign producers a large cost advantage. However, in order to make a fair comparison the quality of

12 Statement Robert Penn.

13 Archivo particular de Gumersindo Torres (AGT) Copiadores 15 Gumersindo Torres to Gómez, 5.12.30. 
TABLE 8

AVERAGE COST OF DELIVERED CRUDE OIL TO THE ATLANTIC SEABOARD: COMPARISON BETWEEN US, VENEZUELA AND REST OF WORLD (INCLUDING VENEZUELA), 1927-1930 (US\$/BARREL)

\begin{tabular}{|l|c|c|c|}
\hline \multirow{2}{*}{\multicolumn{1}{|c|}{ Area of Activity }} & \multicolumn{3}{|c|}{$\mathbf{1 9 2 7 - 1 9 3 0}$} \\
\cline { 2 - 4 } & US Domestic & Venezuela & Rest of the World \\
\hline Cost of Production & 1.09 & 0.62 & 0.87 \\
\hline Selling Costs & 0.04 & 0.0 & 0.0 \\
\hline Pipeline Costs & 0.49 & 0.0 & 0.0 \\
\hline Tanker Charges & 0.265 & 0.25 & 0.28 \\
\hline Total & $\mathbf{1 . 8 8 5}$ & $\mathbf{0 . 8 7}$ & $\mathbf{1 . 1 5}$ \\
\hline
\end{tabular}

Source: US House of Representatives 1932: Adapted Table 25, p. 49.

the crude oil needs to be taken into account and a number of operational adjustments have to be made. In the US, for instance, pipeline charges of $\$ 0.49 /$ barrel accounted for a quarter of the delivery cost of domestic crude, and this was the price charged by the pipeline companies and not the actual cost of transporting the oil. On the other hand, Venezuelan crude oil from the Maracaibo area was transported a short distance by company-owned pipelines, which was included in the overall delivery price to the US. In this respect, US domestic crude oil was slightly overvalued. The biggest adjustment to be made when comparing different grades of crude oil is in the gross value of the petroleum products produced from the various grades of crude oil. In the case of US and Venezuelan crude oil, the gross value of the petroleum products derived from using them was $\$ 2.74 /$ barrel and $\$ 1.71$ / barrel respectively. US refineries using domestic crude oil incurred greater production costs at $\$ 0.73 /$ barrel than refineries using foreign crude at $\$ 0.30$ / barrel ${ }^{14}$. If these costs are deducted from the gross realisations we get a net realisation of $\$ 2.01 /$ barrel for domestic crude oil against $\$ 1.41 /$ barrel for foreign crude oil. This means that foreign crude oil was worth 30 per cent less than domestic oil (US House of Representatives, 1932: Table 27, 53). As foreign crude oil yielded lower quantities of gasoline and fuel oil, then the equivalent average cost of a barrel of domestic oil was $\$ 1.32 /$ barrel (70 per cent of \$1.885), between 1927-1930 compared to the cost of a barrel of Venezuelan oil at $\$ 0.87 /$ barrel. This still gave Venezuelan crude a cost advantage over US crude oil of $\$ 0.45 / \mathrm{barrel}$ and $\$ 0.18 / \mathrm{barrel}$ for foreign crude oil in general.

14 «The Cost of Producing Oil», Oil News, Jan. 14, 1932, pp. 40-41. 
The Tariff Commission's report had an unexpected impact on certain oil companies operating in Venezuela. The Venezuelan government had hitherto accepted the operating costs provided by the companies but in August 1930, Pedro Rincones, the Venezuelan Consul General in New York, alerted Gumersindo Torres, who as Venezuelan Development Minister was responsible for the crude oil industry, that the transport costs between Maracaibo and New York or Philadelphia were approximately 25 cents/barrel, compared to the companies' internal accounting charge of $\$ 0.80 /$ barrel $^{15}$. This was particularly relevant in calculating the government's royalty on crude oil production because it was levied on the net value of crude oil in Venezuela. As Venezuelan crude oil was not traded on any exchange, most of the crude oil production was transferred at a nominal price between subsidiaries of the same company. It was therefore difficult to determine the market value of Venezuelan crude oil. Up to 1929, the Venezuelan government calculated the value of its crude oil by deducting transport costs from prices in New York for a similar grade of crude oil produced in Venezuela. The US Tariff Commission's report revealed that Gulf Oil and Standard Indiana had grossly inflated their transport costs from Venezuela to the US in order to reduce royalty payments. The companies had deducted 67 cents/barrel from the crude oil price instead of the real cost of 23 cents/barrel ${ }^{16}$. The government reacted swiftly to recover the shortfall in taxes by levying an interim payment of 5 cents/barrel, the minimum established by law, as a provisional settlement to the dispute. The companies did not accept any liability because, as Jordan H. Stabler of Gulf Oil argued, the government at the time approved the companies' tax calculations (McBeth, 1983: 192-97).

\section{INCREASED PROFITABILITY OF FOREIGN CRUDE OIL}

The cost advantage of foreign crude oil was reflected in the profit margins of the refineries using it. In 1930, refineries running domestic crude oil made a profit of $\$ 0.11$ or 6 per cent per barrel of crude oil, whereas refineries using Venezuelan and foreign crude oil made a profit of $\$ 0.54$ or 38 per cent per barrel and $\$ 0.26$ or 18 per cent per barrel respectively. Independent refiners were unable to benefit from cheap foreign crude oil because it was priced to compete with domestic crude oil. The average delivered price of Venezuelan crude oil for Independent refiners at the Atlantic Seaboard for 1927-1930 was competitive at \$1.11/barrel, while foreign crude oil was priced at $\$ 1.35 /$ barrel compared with the average "posted» price for domestic crude oil for the same period of $\$ 1.22 /$ barrel at the well-head (see

15 AGT Correspondencia, agosto-diciembre 1930, Pedro Rafael Rincones to Gumersindo Torres, 12.8.30.

16 AGT Correspondencia, enero-junio 1931, Torres to L. F. Calvani, 24.2.31. 
US House of Representatives, 1932). The price of Venezuelan crude oil also included transport costs to the Atlantic Seaboard, with the result that delivery costs at the most important US markets were lower for foreign crude oil than for home-produced crude oil. The large domestic vertically integrated oil companies that also operated foreign oilfields benefited most from this crisis because they were able to «transfer profits from the refining to the production sector» (US House of Representatives, 1932: 4).

At the time, most big US international oil companies produced more crude oil overseas than in America. In 1934, Exxon's overseas production was 268,493 bopd compared with 156,164 bopd in the US. For this reason the Independents considered foreign, mainly Venezuelan, crude oil, a threat to their commercial viability because it allowed the large importers greater control and manipulation of the market. They felt that crude oil importers were using foreign oil to break the Independents and secure effective control of the domestic crude oil industry. With domestic crude oil prices falling to $\$ 0.65 /$ barrel in 1931, mainly because of the discovery of the giant East Texas field in October 1930 and the Depression, in early 1932 the Independents pressed for a tariff of between $\$ 0.42$ - \$1.00/barrel on imported crude oil.

Republican Senator Arthur Capper from Kansas argued that foreign crude oil imports, which accounted for 5.6 per cent of the US market, in effect determined the price structure of the industry. According to Senator Capper, crude oil importers as the marginal suppliers determined the «market price for all the crude oil in this country» (US House of Representatives, 1934: 110) as «no independent refiner dares purchase large quantities of crude in advance when he does not know how much imported crude oil will be thrown on the market» (US House of Representatives, 1934: 110). Exxon, Shell, Standard Indiana and Gulf Oil, the Big Four as Senator Capper referred to them, were responsible for this situation since they controlled the domestic oil industry, accounting for 50 per cent of total crude oil production, 95 per cent of crude oil imports, together with 70 per cent- 80 per cent of refining capacity. Senator Capper reasoned that these companies could at any time break the Independent refiners because they could "throw in enough imported crude, obtained at a very low cost, to break him as a refinery if he had loaded up with crude at a higher price» ${ }^{17}$. Orville Bullington, an Independent producer from Wichita, Texas, thought that foreign crude oil producers acted like a club to "coerce the independent and to break American markets» (US House of Representatives, 1934: 118) ${ }^{18}$, estimating that 300,000 bopd of imported crude oil led to a 500,000 bopd decline in domestic production (US Senate, 1931a: 118). Moreover, consumers did not benefit initially from lower crude prices because there was no short-term link between crude oil prices and refined product prices. Senator

17 US Senate 1931a: 110.

18 Statement by Orville Bullington. 
Capper demonstrated this by showing that when mid-Continent crude oil prices were $\$ 2.04 /$ barrel in 1926, the average price of gasoline in 52 cities was 18.09 cents per gallon, whereas in 1930 the average gasoline price in the same cities had increased to 18.39 cents per gallon with an average crude oil price of $\$ 1.29 /$ barrel. The reason for this is that crude oil demand is derived from demand for refined products and hence has a lower elasticity of demand, with the result that crude oil prices fluctuate more than product prices for a given change in supply. After the discovery of the large East Texas oilfield in 1930, crude oil prices between 1930-31 slumped by 45 per cent, from $\$ 1.19 /$ barrel to $\$ 0.65 /$ barrel $^{19}$, but gasoline prices fell by only 21 per cent (US Tariff Commission, 1946:14), widening the margin between product prices ${ }^{20}$ and crude oil prices as we can see from the chart below. Such a rise in operating margins led to a 31.2 per cent increase in total refining capacity, with the number of refineries rising from 346 in 1931 to 454 three years later (see Schaffer, 1968).

FIGURE 4

GASOLINE/CRUDE OIL DIFFERENTIAL (\%)

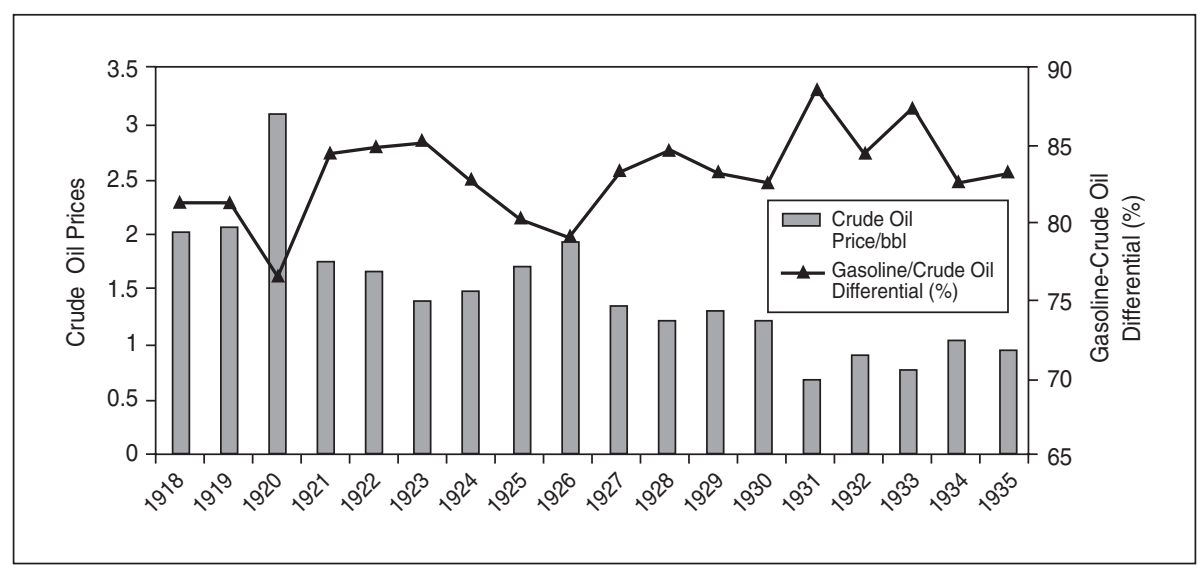

Source: Adapted and calculated from US Tariff Commission, 1946: Table 22, 91.

The Pro-Tariff lobby's most powerful political argument was that foreign crude oil had an adverse impact on employment and there was no point in further aggravating the unemployment problem created by the Great Depression. It was estimated that the Independents employed approximately

\footnotetext{
19 At one stage crude oil prices in East Texas plummeted to 4 cents per barrel (Brand, 1983: 106).

20 US Congressional Record, Vol. 76 Part 2, Jan. 3 1933-Jan. 23 1933, 72 Cong. 2 Sess., p. 2158.
} 
two million people directly and a further 22 million people depended on them indirectly for their livelihood ${ }^{21}$. Edward F. McGrady, the Washington representative of the American Federation of Labor, estimated that crude oil imports would make a further 800,000 people redundant (US Senate, 1931a: 60). The US Congress found, in its investigation on the concentration of economic power in 1940, that the oil industry was harder hit by the Great Depression than rest of the economy and did not recover until 1935 as we can see in Figure 5. Such arguments resonated with the general population who believed that foreign competition was harming the domestic crude oil industry.

FIGURE 5

RELATIVE MOVEMENT OF NET INCOME OF OIL PRODUCING AND REFINING COS. COMPARED WITH 735 INDUSTRIAL COS. AND 960 CORPS., 1926-1938 $(1929=100)$

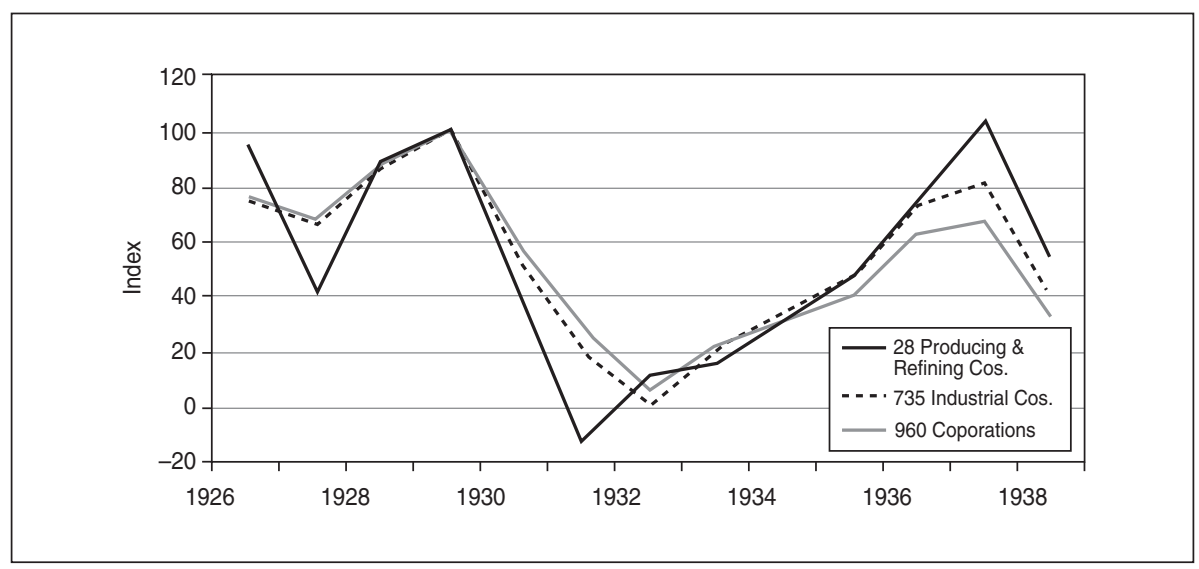

Source: Adapted from US House of Representatives, 1940: Table E, p. 7706.

\section{FOREIGN CRUDE OIL WINNERS}

The Eastern Seaboard states were opposed to curbing crude oil imports because they benefited most from imported crude oil as it arrived directly by sea. The 16 Eastern Seaboard states consumed 128 million barrels of oil a year, of which 23 per cent was imported from the Dutch West Indies or Venezuela, giving the population a chance to «purchase gasoline at prices comparable to those prevailing near the producing regions and refineries of the Middle East»

21 Wirt Franklin to Senator Samuel M Shortbridge, 11.12.31 in Congressional Record, vol. 75 Part 1, December 7-22, 1931, 72 Cong. 1 Sess., p. 497. 
(US Senate, 1931a: 180) ${ }^{22}$. Republican Representative John E. Nelson of Maine explained that the long haulage cost of raw materials from other parts of the US to the state and the return haul to market of the finished products made it difficult for state manufacturers to compete with other regions. Maine's newsprint industry and 67 per cent of the public utilities, which represented a total of US $\$ 125$ million of capital employed, depended on crude oil. The imposition of a tariff on foreign crude oil would create severe problems for the local newsprint industry, which competed against stiff Canadian opposition. It was estimated that lower crude oil imports added 6 cents per gallon to the price of gasoline in New England because of higher transport costs, placing an estimated additional annual burden of $\$ 3,286,680$ on the farmers of Maine alone (US Senate, 1931a: 180). The state of Maryland also opposed restricting foreign crude oil imports. Baltimore was the third largest importer of foreign crude oil accounting for 11 per cent of total US crude oil imports, with the large refineries at Bayonne and Marcus Hook processing Venezuelan crude oil. George H. Powder, Executive Vice President of the Baltimore Association of Commerce, stated that a tariff on foreign crude oil would have «serious consequences to Baltimore shipping, port and industrial activity» (US Senate, 1931a: 196) ${ }^{23}$.

\section{PROTECTIONISM IS CALLED FOR}

At the beginning of February 1931, Senator Capper of Kansas, where many small oil producers had lost their livelihood because the Prairie Oil \& Gas Co. had stopped purchasing their meagre individual production, introduced a bill in Congress to place an embargo on foreign crude oil ${ }^{24}$. Later in the month, the Senate Commerce Committee voted (9-6) in favour of Senator Capper's bill to limit crude oil imports to 16 million barrels per annum for three years together with a total embargo on gasoline imports. In the House of Representatives, Homer Hoch, Republican representative for Kansas, tried to convince the House Ways and Means Committee to follow the Senate's lead in limiting crude oil imports ${ }^{25}$. Such a move would reduce crude oil imports from 6.9 per cent to 1.8 per cent of total domestic crude oil production ${ }^{26}$. This raised the hopes of the Independents that Venezuelan crude oil imports would be curtailed ${ }^{27}$, while causing consternation both

22 Statement Hon. John E. Nelson.

23 Statement. George H. Powder.

24 Cfr. «OilEmbargo? Merger?»,Time, 16.2.31 in http://www/time/magazine/article/0,9,71,7410941,00.html.

25 Ibid.

26 Calculated from data supplied by the US Energy Information Administration at http://tonto. eia.doe.gov/dnav/pet/pet_sum_crdsnd_adc_mbbl_m.htm.

27 Archivo Histórico de Miraflores, Secretaría General de la Presidencia de la República, Correspondencia Presidencial (AHMSGPRCP) Feb 11-20 1931JVG Pedro Manuel Arcaya to Juan Vicente Gómez, 20.2.31. 
among "those interested in the Venezuelan oil industry» ${ }^{28}$ and the Venezuelan government, which felt the country's oil industry would be adversely affected. Torres and Pedro M. Arcaya, Venezuelan Minister in the US, kept a close watch on events unfolding in Washington. Arcaya sent daily reports to Torres ${ }^{29}$ and also pointed out to Gómez that the US government was against restricting Venezuelan crude oil imports ${ }^{30}$ but that Congress would act as it deemed fit and in the best interests of the country.

After considering all the above arguments, on February 23, 1931 a SubCommittee of the House of Representatives Ways and Means Committee headed by Congressman Nicholas Longworth, the Republican Representative from Ohio and Speaker of the House, recommended postponing a decision on the petroleum oil embargo bill. Arcaya attributed this result to his insistence that the State Department intervene on behalf of Venezuela, informing Gómez that «I am extremely proud that my efforts at defending Venezuela's interests at the State Department have been so successful» ${ }^{31}$. The oil states however did not receive the postponement with equanimity, with Hoch, Ulysses Samuel Guyer, Charles Isaac Sparks, William Purnell Lambertson, and James George Strong, the Kansas Republican representatives, threatening New England with a domestic oil embargo if they did not vote for a restriction of foreign crude oil imports ${ }^{32}$. On February 25, Congressman Longworth called a meeting at the office of Republican Congressman Willis Chatman Hawley of Oregon, Chairman of the Ways and Means Committee, to request that crude oil imports be included in the forthcoming Hawley-Smoot Tariff Act ${ }^{33}$. Hoch, representing the other oil states, and Nelson of Maine were also present. After a few days of secret discussions, the Ways and Means Committee sanctioned the Sub-Committee's recommendation for a postponement, with Congress ending its session on March 6 without reaching a decision.

The lobbying to restrict crude oil imports continued unabated. On March 1, Governor William Henry Murray of Oklahoma, his cousin Cicero Irvin Murray, an oilman, Governor Ross Shaw Sterling of Texas, together with representatives of the Governors of Kansas and New Mexico, and Robert R. Penn, Vice President of the API, urged President Herbert Hoover to force the large crude oil importers to reduce their imports voluntarily. Shell, Exxon, Standard Indiana, Gulf Oil, Sinclair Oil and Cities Services considered this suggestion at a meeting at Texakana (Texas) with the oil-producing states. A gentleman's agreement was reached to maintain the reduction of imports

\footnotetext{
28 AGT Correspondencia, enero-junio 1931, Rincones to Torres, 9.2.31.

29 AGT Copiadores, 15 Telegram Torres to Gómez, 11.2.31.

30 AHMSGPRCP, enero 1-10 1931JVG Arcaya to Gómez, 6.2.31.

31 AHMSGPRCP, febrero 21-28 1931JVG Arcaya to Gómez, 23.2.31.

32 AHMSGPRCP, marzo 1-14 1931JVG Journal of Commerce, 27.2.31.

33 The Hawley-Smoot Act introduced a high level of protective tariffs on farm and manufactured products and was approved by Congress in June 1931.
} 
by 25 per cent, with Shell keeping its 50 per cent curtailment of imports in place. Such a reduction would have a serious impact on the financial position of Venezuela, with Arcaya estimating that oil taxes could decline by 24 per cent from $\$ 11.6$ million in 1930 to $\$ 7.8$ million in $1931^{34}$. The direct impact in Venezuela was a drastic reduction in capital expenditure, with the number of wells drilled declining from an annual average of 451 wells between 1926 and 1930 to an average of 178 wells between 1931 and 1935, with only 89 wells drilled in 1932 (see Figure 1). Arcaya, nevertheless, welcomed the agreement because it was better than the "complete prohibition that Congress wanted to enact» ${ }^{35}$. For the rest of the year, the companies adhered to the agreement by diverting their foreign-produced crude oil to European markets. At the same time, overall global demand for crude oil declined because of the Great Depression, with oil production in Venezuela falling by 13.5 per cent from 370,537 bopd in 1930 to 320,200 bopd in 1931 (Venezuela, Ministerio de Minas e Hidrocarburos, Dirección General, 1964: 138-9) and remained flat until 1933 (see Figure 3).

The industry's curtailment of crude oil imports in 1931 was only a temporary measure as in early March the House approved Milton Cline Garber's (Republican Representative from Oklahoma) resolution to extend coverage of the Hawley-Smoot Tariff Act to allow the Tariff Commission to determine the cost difference between domestic and foreign crude oil production ${ }^{36}$. This was the first step towards placing foreign crude oil under the Tariff Protection Act at the next session of Congress. During the year crude oil prices continued to fall, and with the unsuccessful efforts of the lower Federal Courts to regulate oil production, the Governors' Oil State Advisory Committee met to co-ordinate prorationing in the producing states. The aggregate effect of the various means used to reduce oil supplies together with the impact of the Depression, which curtailed investment, was that domestic production and imports fell during 1930-1932 (Figure 7), with oil prices reaching their lowest level in July 1931 of US $\$ 0.24$ per barrel because of the continuing flow of "hot-oil» ${ }^{37}$ and the rise in production capacity ready to reach market. Foreign crude oil bore the brunt of the Independents' criticism.

At the end of 1931, the US Treasury was looking for additional revenue to reduce its estimated budget deficit of $\$ 900$ million and the strong possibility of it deepening further the following year because of a prolonged economic depression. In order to breach this gap, the House Ways and Means Committee recommended increasing income and estate taxes, while the Senate

34 AHMSGPR, J. B. Pérez, Feb 1-28 1931 Arcaya to Gómez, 31.3.31. The author has converted the numbers given by Arcaya in Venezuelan Bolivars to US dollars using the average exchange rate for the year.

35 AHMSGPRCP, J. B. Pérez, Feb 1-28 1931(sic) Arcaya to Gómez, 31.3.31.

36 AHMSGPRCP, marzo 1-14 1931, JVG, Trans. Journal of Commerce, 4.3.31.

37 This was oil produced illegally over the quota set for an oilfield. 
Finance Committee also wanted to impose higher income taxes and increase import duties on raw materials, including a tax on foreign crude oil imports that was expected to raise $\$ 150$ million (see Blakeley \& Blakeley, 1932). This played into the hands of those advocating a curtailment of crude oil imports. Republican Congressman Garber felt that the demise of the crude oil industry only served to exacerbate further the economic depression in the country. Congressman Guyer of Kansas estimated that the rental income of $\$ 10.5$ million per annum paid by the oil companies in Kansas alone would be lost with the industry's slowdown, reducing aggregate demand in the economy ${ }^{38}$. Furthermore, a shrinking crude oil industry would lead to a significant overall reduction in tax revenues. Franklin, representing the Independents, estimated that between 1912 and 1932 the industry earned net profits of $\$ 2$ million but paid $\$ 5$ billion in taxes (see US House of Representatives, 1934a) ${ }^{39}$. Uren confirms this high rate of tax, with the industry paying taxes that averaged 332.5 per cent of net earnings between 1934 and 1939 (Uren, 1950: Table XXXV, 342).

At the beginning of 1932 it was clear to the large crude oil importing companies that an import tariff would be levied on foreign crude oil and they started planning for such an event by increasing the amount of crude oil shipped to the US. According to Willard Jones, the Director of the Marine Department of the Gulf Refining Co., during the first six months of the year the companies imported large quantities of crude oil, «enough to supply the needs of the Eastern Seaboard until December of this year» ${ }^{40}$. In spite of the various arguments against the tariff, the Independents finally won the argument and on April 26 the House Ways and Means Committee approved an amendment to the Revenue Bill to impose a $\$ 0.42 /$ barrel tariff on crude oil imports ${ }^{41}$. The Independents then got the full Senate to debate the imposition of a tariff ${ }^{42}$.

\section{VENEZUELA'S RESPONSE}

The Venezuelan government was dismayed at these events because it felt that a US crude oil import tariff would lead to a severe decline in the country's crude oil production. It was clear that the economic and political effects for the Gómez regime would be dire if the companies pulled out of the country. Arcaya continued rallying support for Venezuela at the State Department and sent a Memorandum to Assistant Secretary of State, Francis White, detailing the impact the tariff would have on American commercial interests in the country, which was already suffering the effects of the world

\footnotetext{
38 Congressional Record, vol. 75 Part 10, 72 Cong 1 Sess., May 18-31 1932, p. 11474.

39 Statement Wirt Franklin.

40 AHMSGPRCP, junio 16-30 1932, Rincones to Gómez, 25.6.32.

41 AHMSGPRCS, abril 21-30 1932, Arcaya to Pedro Itriago Chacín, 26.4.32.

42 Ibid.
} 
economic depression. According to Arcaya, many Americans working in the oilfields would be made redundant and sales of American equipment to the oil industry would decline ${ }^{43}$. Arcaya explained to Gómez on April 24, 1932 that he felt that his representations had had the desired effect as there was a strong possibility that the Senate would reject the tariff ${ }^{44}$. The State Department succeeded in getting the Senate Finance Committee to suspend its decision temporarily ${ }^{45}$. Democrat Senator Millard Evelyn Tydings of Maryland defended Venezuela's interests by stating on May 23, 1932 that the wages paid to American workers in the country were not low and that the subsistence allowance paid was higher than "in any oil field in America» ${ }^{46}$. Senator Tydings, using the Lago Petroleum Corp.'s payroll for its foreign employees as reference, concluded that Venezuelan crude oil did not have a cost advantage over domestic crude oil (Table 3).

TABLE 9

APPROXIMATE WAGE RATE, LAGO PETROLEUM CORPORATION, VENEZUELA

\begin{tabular}{|l|c|c|c|c|}
\hline \multicolumn{1}{|c|}{ Classification } & $\begin{array}{c}\text { Average Salary } \\
\text { per month } \\
\text { (US\$) }\end{array}$ & $\begin{array}{c}\text { Cost of } \\
\text { Subsistence } \\
\text { (US\$) }\end{array}$ & $\begin{array}{c}\text { Vacation } \\
\text { Costs } \\
\text { (US\$) }\end{array}$ & $\begin{array}{c}\text { Approximate } \\
\text { Total } \\
\text { per month } \\
\text { (US\$) }\end{array}$ \\
\hline Drillers & 350 & 123 & 29 & 502 \\
\hline Toolpushers & 450 & 123 & 37 & 610 \\
\hline Machinists & 250 & 123 & 21 & 394 \\
\hline Boilermaker & 225 & 123 & 19 & 367 \\
\hline Geologist & $225-400$ & 123 & $19-33$ & $367-556$ \\
\hline Sternorgraphers & $150-250$ & 123 & $12-21$ & $285-394$ \\
\hline Clerks & $150-300$ & 123 & $12-25$ & $285-448$ \\
\hline Pipeline foremen & $275-350$ & 123 & $23-25$ & $421-502$ \\
\hline Gaugers & $150-200$ & 123 & $12-17$ & $285-340$ \\
\hline Engineers & $225-350$ & 123 & $19-29$ & $367-402$ \\
\hline Electric Foremen & $250-300$ & 123 & $21-25$ & $394-448$ \\
\hline Accountants & $175-385$ & 123 & $14-32$ & $312-540$ \\
\hline
\end{tabular}

Source: US House of Representatives 1931: 276.

43 Archivo Histórico de Miraflores, Secretaría General de la Presidencia de la República, Correspondencia del Secretario General (AHMSGPRCS), abril 21-30 1932, Arcaya to Francis White, 22.4.32.

44 AHMSGPRCP, abril 21-30 1932, Arcaya to Gómez, 26.4.32.

45 AHMSGPRCP, mayo 1-10 1932, Arcaya to Gómez, 3.5.32.

46 Congressional Record, vol. 75, Part 10, 72 Cong. 1 Sess., May 18-21, 1932, p. 10926. 
Among the large crude oil importers, Standard Indiana was Venezuela's strongest supporter because of its interests in the country and Mexico through its ownership of PAPT ${ }^{47}$. Paul H. Harwood, PAPT's Vice President, stated that the tariff constituted a "partial embargo aimed at American interests abroad» ${ }^{48}$. However, in April 1932 the Venezuelan government was less worried about the possibility of a tariff because Exxon purchased PAPT for US\$194 million (see McDermond, 1932), and would now «monopolize the European market with our crude oil» ${ }^{49}$. The acquisition of PAPT brought not only a large crude oil production base but also a big 87,500 bopd export refinery in Aruba, Dutch West Indies, that Exxon would use to supply its European markets at "lower costs than could refineries in the United States» (Larson, Knowlton \& Popple, 171: 281). Hence, Exxon was not opposed to a crude oil import tariff because with higher domestic crude oil prices it «expected to generate large profits and will increase its Venezuelan production to take over the world oil market with our oil» ${ }^{50}$, so that there «is little fear that crude oil production will decline» ${ }^{51}$.

\section{IMPOSITION OF A TARIFF}

At the end of April, the Senate Committee re-established the tariff on foreign crude oil but at a reduced rate while increasing the levy on gasoline and other refined products. In spite of last minute lobbying, on June 6 President Hoover signed the Revenue Bill that included a comprehensive oil-tariff bill that was applicable to domestically consumed imports. Crude oil and heavycrude products were taxed at $\$ 0.21 /$ barrel, with gasoline and other motor fuels at $\$ 1.05 /$ barrel and lubricating oil at $\$ 1.68 /$ barrel (Table 10).

The US Treasury decided that «crude oil in bond, to be used in making refined products for exports, and fuel oil to be used as supplies for ships engaged in foreign trade could be imported free of tax» (US Tariff Commission, 1946: 75). This meant that bonded foreign oil could be refined in the US and the products derived from it exported, with the result that Venezuelan crude increased its share of the European market by replacing part of the US domestic oil exported previously to the continent (see Table 11).

Although gasoline imports to the US were negligible after the imposition of the 1932 tariff, Venezuelan crude oil still entered the US in large quantities. At first, foreign imports declined from 88 million barrels in 1931 to 44

47 PAPT owned the Lago Petroleum Corp., that held a 1.16 million hectare concession over Lake Maracaibo (cfr. Skinner 1936)

48 FO 371/15860 Sir R. Lindsay to Foreign Office, 10.4.32.

49 AHMSGPRCP, mayo 1-10 1932, Arcaya to Gómez, 3.5.32.

50 AHMSGPRCP, junio 1-15 1932, Arcaya to Gómez, 7.6.32.

51 Ibid. 
TABLE 10

US TARIFF ON FOREIGN OIL \& PRODUCTS

\begin{tabular}{|l|c|}
\hline \multicolumn{1}{|c|}{ Item } & Tariff (US\$/barrel) \\
\hline Crude Oil & 0.21 \\
\hline Heavy Crude Oil Products & 0.21 \\
\hline Gasoline \& Other & 1.05 \\
\hline Motor Fuels & 1.05 \\
\hline Lubricating Oil & 1.68 \\
\hline Wax Products (per pound) & 0.01 \\
\hline
\end{tabular}

Source: Adapted, US Tariff Commission 1946: 75.

TABLE 11

CHANGE OF CRUDE OIL IMPORTS INTO EUROPE, 1928-1933 (\%)

\begin{tabular}{|c|c|c|c|c|c|}
\hline Year & USA & $\begin{array}{c}\text { Venezuela \& } \\
\text { Dutch West } \\
\text { Indies }\end{array}$ & Romania & Russia & Persia \\
\hline 1928 & 38.8 & 13.4 & 7.8 & 8.4 & 14.2 \\
\hline 1929 & 34.8 & 12.5 & 8.5 & 10.3 & 13.7 \\
\hline 1930 & 33.5 & 13.0 & 10.3 & 12.3 & 13.6 \\
\hline 1931 & 27.3 & 14.5 & 12.5 & 14.4 & 13.4 \\
\hline 1932 & 21.5 & 15.3 & 13.4 & 15.8 & 13.6 \\
\hline 1933 & 18.6 & 21.4 & 13.6 & 11.1 & 13.0 \\
\hline
\end{tabular}

Source: Adapted, «Shifts in European supply and the Iraq Oil», Petroleum Press Service, 1:5, Aug. 1, 1934, pp.1-3, p. 2.

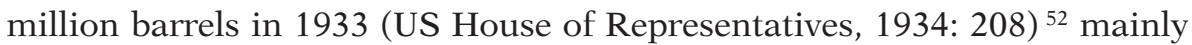
because of the economic depression, but then gradually increased, averaging 59 million barrels for 1937-1938 (US Tariff Commission, 1946). At the same time, the tariff had the effect of increasing Venezuelan crude oil supplies to Europe both directly and as refined products from the US, with the country becoming the largest crude oil supplier to Europe in the mid-1930s with 20 per cent of the market ${ }^{53}$. Figure 6 shows that Venezuelan oil exports to the US declined during the early part of the 1930s with crude oil exports

52 Statement Arthur H. Redfield.

53 «Shifts in European supply and the Iraq Oil», Petroleum Press Service, 1 (5), Aug. 1, 1934, pp. $1-3$, p. 2. 
to Europe rising rapidly. Venezuela's share of Britain's crude oil market increased significantly, from 17 per cent at the beginning of the 1930s to 49 per cent at the outset of World War II (Butler, 1959: Table 2, 190). Venezuela also assumed greater strategic military importance for the UK because in the event of a war in which the US remained an "unfriendly» neutral, defined as the US supplying crude oil only for military use and not for civilian consumption, the South American nation would be the main British crude oil supplier, delivering 44.4 per cent of its military needs both East and West of Suez, and all civilian demand ${ }^{54}$.

FIGURE 6

VENEZUELAN OIL PRODUCTION \& EXPORTS TO THE US AND EUROPE (000S BBLS)

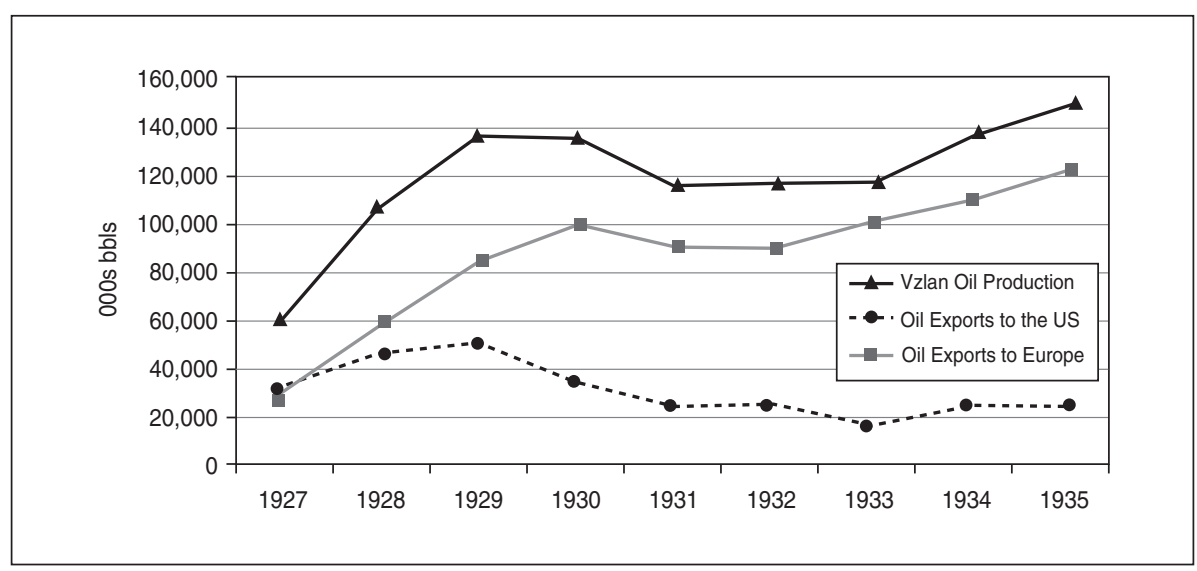

Source: Calculated from Brown 1985: 384 and Venezuela, Ministry of Mines and Hydrocarbons, Directorate General, 1966: 1.

The 1932 tariff, as Bradley has argued, reduced the role played by the US in the "world petroleum market» (Bradley, 1989: 43), with lower crude oil imports and US crude oil exports increasing in nominal terms but declining in relation to its domestic crude oil production from 13.4 per cent in 1929 to 7.9 per cent in 1935 (Williamson, 1963: 649).

54 UK National Archives, Cabinet Office, CAB 50/3/Secret/O.B. 27 Committee on Imperial Defence, Oil Board, Sub-Committee's Report on Oil Supply in Time of War, March 20, 1929. 
FIGURE 7

US CRUDE IMPORTS/EXPORTS, 1927-1935 (000S BBLS)

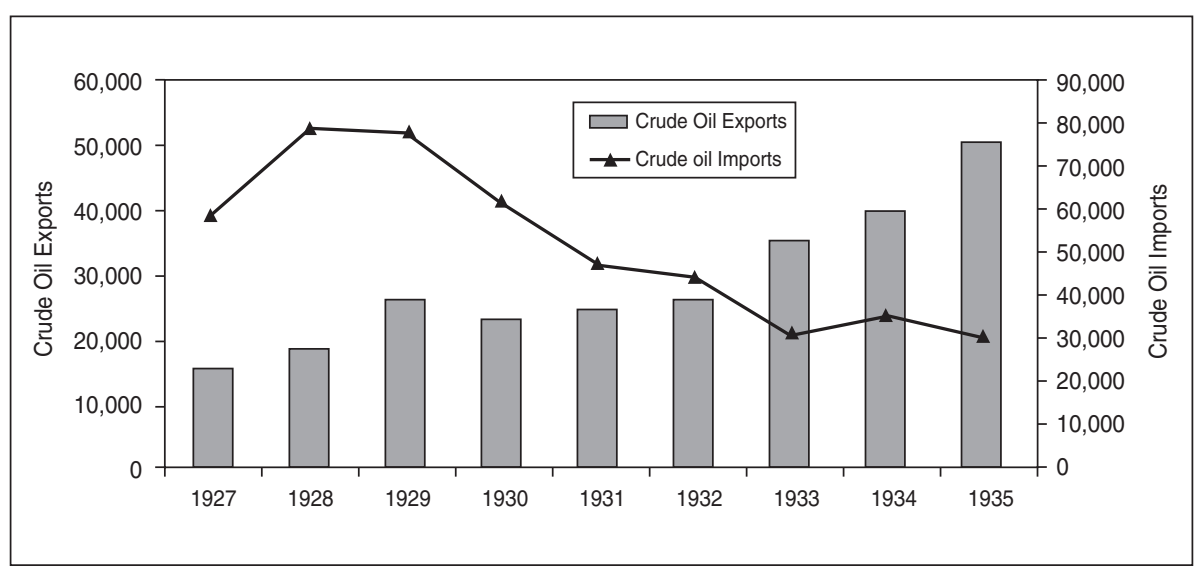

Source: Calculated from http://tonto.eia.doe.gov/dnav/pet/hist/mcrexus1a.htm.

\section{EFFECTS OF THE TARIFF}

The Independents interpreted the enactment of the crude oil tariff as a reinforcement of the voluntary quota and hence their crude oil reserves received greater protection. Soon after the tariff was imposed, US crude oil production recovered from a low of 2.15 million bopd in 1932 to 2.49 million bopd in $1933^{55}$. The large crude oil importers also benefited because the high tariff on gasoline imports was compensated by the protection of their domestic refining business and they could now process low cost foreign oil to export petroleum products to Europe. The big crude oil importers of Exxon and Gulf Oil were better off than Shell, which had hitherto imported large quantities of inexpensive gasoline that was now subject to a hefty tariff. After paying the new tariff, Venezuelan crude oil was still competitive with a cost advantage of \$0.25/barrel over domestic crude oil (Knudson, 1975: 59). Foreign crude oil imports declined from 47.2 million barrels in 1931 (5.6 per cent of total domestic crude oil production) to 32.2 million barrels in $1935^{56}$ (3.2 per cent of total domestic crude oil production), mainly because of the economic depression.

In Venezuela the tariff, together with the Great Depression, had the effect of slowing development of the country's oil industry, with production

55 Calculated from data supplied by the US Energy Information Administration at http://tonto. eia.doe.gov/dnav/pet/pet sum crdsnd adc mbbl m.htm.

56 Cfr. http://tonto.eia.doe.gov/dnav/pet/pet_move_imp_dc_nus-z00_mbbl_m.htm. 
remaining flat between 1932-35 and drilling activity shrinking by 40 per cent compared to the previous five years (see Figures 1 and 2) and total investment in the industry declining from US\$189 million in 1930 to an average of US $\$ 81.2$ million between 1931 and 1935. It also weakened the government's bargaining power with the oil companies. Arcaya counselled Gómez that the only hope of maintaining current government oil taxes was for Exxon and the other oil companies to be encouraged to remain in the country and continue producing crude oil. This meant dropping a legal tax dispute with Exxon and Gulf Oil because otherwise the companies could retaliate by abandoning their concessions and other companies would be reluctant to acquire them because of the "economic crisis that affects us all and would therefore have a deleterious effect on government revenues ${ }^{57}$. Consequently, any agreement with the companies was «better than a protracted legal battle that could prove counterproductive to us» ${ }^{58}$. Moreover, all actions that lessened the companies' confidence in the government should be avoided because it was «a time of fear and distrust of capital» ${ }^{59}$.

\section{PRO-RATIONING OF CRUDE OIL PRODUCTION}

With domestic crude oil production rising as a result of the new tariff and crude oil prices remaining low, the lobbying of Congress continued for further restrictions on foreign crude oil ${ }^{60}$. On March 27, 1933 a few weeks after President Franklin Delano Roosevelt began his administration, Interior Secretary Harold L. Ickes held a meeting between the oil State Governors and the oil companies to discuss a proposed Code of Fair Competition for the industry. At the meeting there was talk of conservation but according to Engler, "prices, profits and private rights clearly took precedence among the oilmen worried about the chances for maintaining a social environment that had long endowed property with economic and political power» (Engler, 1961: 138). The API wanted further Federal intervention to bring stability to the industry by ending flush and famine cycles, while the IPAA called for domestic production together with a price code and for foreign crude oil imports to be limited to the average volumes imported during the previous six months. In the end, tempered by the demands of the Independents, the government agreed to bring production into line with consumption and to support State prorationing laws. This was done through the National Industrial Recovery Act (NIRA), enacted on June 16, 1933, with the oil in-

57 AHMSGPRCP, mayo 23-31 1932, Arcaya to Gómez, 31.5.32.

58 Ibid.

59 AHMSGPRCP, junio 1-15 1932, Arcaya to Gómez, 9.6.32. On a separate issue, Arcaya also felt that a dangerous precedent would be established if the concessions held by Shell's subsidiary, the Caribbean Petroleum Company, were annulled (ibid.).

60 US Congressional Record, vol. 76, Part 2, 72 Cong. 2 Sess., January 3-23 1933, p. 2158. 
dustry singled out for special federal legislation under section 9c of the Act that dealt with output control. President Roosevelt also issued an executive order reaffirming the government's right to control both interstate and the foreign movement of crude oil and its products either from production or from storage over and above that established by regulation and state quotas. This was formalised on August 9, 1933 with the enactment of the Code of Fair Competition for the Petroleum Industry, which followed closely the IPAA demands of matching domestic production of crude oil to consumption and restricting crude oil imports to the average of the last six months in 1932. The primary function of the Code was to restore parity for crude oil through the control of production allowed under State prorationing laws. In doing so it broke, as Chazeau and Kahn suggest, the «nexus between oil discoveries and short-run price»(De Chazeau \& Kahn, 1973: 164) as the States were now in a position to «control the supply of oil on the national market and hence its price» (Rostow, 1948: 48). The industry was still in "the hands of the giant oil purchasing companies» (Engler, 1961: 149) because they controlled much of the production, pipeline, refineries, and markets, and viewed oil operations on a global scale rather than a national one. The Code was also undermined by the continued delivery of «hot oil» between states.

The control of crude oil supplies stabilised crude oil prices at a relatively high level, which between July and October 1933 doubled from \$0.50/barrel to $\$ 1.00 /$ barrel (see US House of Representatives, 1940). Prorationing brought about a more orderly marketing of crude oil with fewer and less extreme price changes at the expense of lowering the present value of existing reserves because of the «extension of time for ultimate recovery either of cost or value» (De Chazeau \& Kahn, 1973: 164). This impacted adversely on the balance sheets of some of the smaller producers because it lengthened the amortisation of past capital expenditure and increased fixed operating costs per barrel. Such a situation boosted the possibility of small operators with limited capital resources going bankrupt as their revenue stream could only rise with increased production, with many of them acquired by companies with strong balance sheets (see Cook, 1941). At the same time, the large integrated oil companies increased their profitability by improving the balance between their producing and refining and marketing operations. The prorationing system also discouraged investment in crude oil exploration, releasing substantial net cash flows that were used to reduce corporate debt and thereby strengthening their balance sheets. The American oil industry was one of the few major industries that emerged out of the Great Depression in a stronger financial position ${ }^{61}$, with the debt held by the 15 largest oil companies between 1929 and 1933 declining by 17.6 per cent from

61 Cfr. «Financial Position of American Oil Industry Strengthened during Depression», Petroleum Press Service, vol. 1 (18), Sept. 15, 1934, pp. 4-5. 
$\$ 820,254,833$ to $\$ 675,855,443^{62}$. The recovery in the industry's profitability after 1933, as Del Sesto shows (US House of Representatives, 1940a: 9607), was directly linked to the prorationing system, with net profits for 16 oil companies rising by 28 per cent from US $\$ 21,416,000$ in the third quarter of 1934 to US $\$ 27,437,383$ in the equivalent quarter in $1935^{63}$. The large crude oil importers also benefited from a system that established a stable domestic market with relatively high crude oil prices while allowing them to supply foreign markets with cheap Venezuelan crude oil that was sold using the Gulf+ pricing structure of crude oil prices then in use ${ }^{64}$.

\section{CONCLUSION}

The development of the Venezuelan oil industry coincided with the feast and famine cycle that the US crude oil industry went through during the 1920s. After World War I, it was predicted that the US was running out of crude oil reserves with the government urging oil companies to develop foreign petroleum reserves. After 1922 the Venezuelan crude oil industry developed at an astonishing pace, becoming within six years the second largest crude oil producer in the world after the US. The decline in US petroleum reserves was reversed during the decade with the discovery of large oilfields in Arkansas, California, Oklahoma and Texas. As a result, crude oil prices plummeted with the Independents blaming foreign, mainly Venezuelan, crude oil imports, which accounted for around 2 per cent of domestic crude oil production, for the fall in prices. The refining industry, with lower feedstock prices, achieved higher operating margins that were not passed on to the consumer. Crude oil imports served as a good scapegoat for both companies and government, with Congress believing that it was having an adverse impact on the economy. The Independents eventually persuaded the government to impose a tariff on crude oil imports and to peg state oil production to consumption. Such interference in a free market economy by the government stabilised crude oil prices and effectively barred Venezuelan crude oil from competing in terms of price with domestic crude oil to the detriment of consumers unable to take advantage of lower prices. This also meant that crude oil production in Venezuela did not decline as much as was anticipated at the time.

The large American crude oil importers were interested in stabilising the domestic US market at relatively high crude oil prices, an objective which was achieved by the tariff and the pro-rationing of crude oil production. This allowed the large international oil companies, which had already dealt with

\footnotetext{
62 Ibid.

63 "Growing Profits of US Oil Industry», Petroleum Press Service, vol. 2 (22), pp. 3-4.

64 The Gulf+ pricing structure was based on Platt's Oilgram Price Service.
} 
world crude oil production and the threat of synthetic crude oil with the «As Is» and I G Farben agreements respectively, to supply foreign markets with cheap Venezuelan crude oil while charging high US oil prices through the Gulf+ pricing structure. The international oil companies shifted their Venezuelan crude oil supplies away from the US to Europe both directly and indirectly by processing part of their Venezuelan crude oil in their US refineries and exporting petroleum products. This was especially relevant for the Eastern Seaboard refineries, which prior to the enactment of the tariff, felt that their commercial competitiveness would decline. Moreover, the shift in Venezuelan crude oil supplies to Europe meant that crude oil production in the country did not decline as much as was anticipated at the time. The post-tariff system linked Venezuela's interests directly with those of the large US crude oil importing companies. This had two distinct advantages for the government: first, it assured rising crude oil production and, secondly, high US oil prices meant that royalty payments as a percentage of the value of crude oil were higher. Venezuela's oil revenues then depended on the country's competitiveness and attractiveness to the oil companies in order for them to continue producing crude oil. The development of the Venezuelan oil industry and the experience of the 1932 US tariff on foreign crude oil revealed to the Venezuelan government its lack of control over the development of the industry, and its dependence on the continuous growth of crude oil production geared to the requirements of the American and European markets.

\section{BIBLIOGRAPHY}

\section{Archives \& Oficial Documents}

Archivo Histórico de Miraflores, Secretaría General de la Presidencia de la República, Correspondencia Presidencial, 1927-1935.

Archivo Histórico de Miraflores, Secretaría General de la Presidencia de la República, Correspondencia del Secretario General, 1927-1935.

Archivo particular de Gumersindo Torres, Correspondencia, 1927-1935.

Archivo particular del Dr. Gumersindo Torres, Copiadores, 1927-1935.

Cook, Roy C. (1941): Control of the Petroleum Industry by Major Oil Companies. Temporary National Economic Committee - Investigation of Concentration of Economic Power-, Senate Committee Print Monograph No. 39, 76 Cong 3 Sess. Washington, USGPO.

«Financial Position of American Oil Industry Strengthened during Depression». Petroleum Press Service, 1:18, pp. 4-5, Sept. 15, 1934.

Herrera F. R. (1920): «Datos sobre la Industria Petrolífera en Venezuela». Boletín del Ministerio de Fomento, 1 (2), pp. 2-16.

Latin American World, 14: 5, 51, January 1933.

«Growing Profits of US Oil Industry». Petroleum Press Service, 2:22, pp. 3-4, 1935.

«OilEmbargo? Merger?».Time,16.2.31 inhttp://www/time/magazine/article/0,9,71,7410941,00.html. 
Osborne, J. B. (1912): «Protection of American Commerce and Capital Abroad». North American Review, 195, pp. 687-700.

«Shifts in European supply and the Iraq Oil». Petroleum Press Service, 1: 5, pp. 1-3, 1934. «The Cost of Producing Oil». Oil News, Jan. 14, 1932, pp. 40-41.

UK National Archives, Cabinet Office, Committee of Imperial Defence, Oil Board, 19271935.

UK National Archives, Foreign Office, General Correspondence, Political, 1927-1935.

US Congressional Record, 1927-35.

US Energy Information Administration at http://tonto.eia.doe.gov/dnav/pet/pet sum crdsnd adc mbbl_m.htm.

US House of Representatives (1931): «Regulating importation of petroleum and related products». Hearings before the Committee on Ways \& Means, 71 Cong., 3 Sess. Washington, USGPO.

- (1932): «Production Costs of Crude Petroleum and of Refined Petroleum Products». House Document No. 195, 72 Cong. 1 Sess. Washington: USGPO.

- (1934): «Petroleum Investigation». Hearings before a Sub-Committee of the Committee on Interstate and Foreign Commerce, Part 1, 73 Cong. (Recess). Washington, USGPO.

- (1934a): «Petroleum Investigation». Hearings before a Sub-Committee of the Committee on Interstate and Foreign Commerce, Part 3, 73 Cong. (Recess). Washington, USGPO.

- (1940): Petroleum Industry. Investigation of Economic Power, Hearings before the Temporary National Economic Committee, Part 14, Section 1, 76 Cong. 1 Sess. Washington, USGPO.

- (1940a): Petroleum Industry Investigation of Concentration of Economic Power. Hearings before the Temporary National Economic Committee, Part 17, Section 4, 76 Congress, 1 Sess. Washington, USGPO.

- (1950): «Effects of Foreign Oil Importers on Independent Domestic Producers». A Report of the Sub-Committee on Oil Imports to the Select Committee on Small Businesses', House Report No. 2344, 81 Cong. 2 Sess. Washington: USGPO.

US Government, Records of the Department of State relating to the Internal Affairs of Venezuela (DS) 831.6363/284 Department of State, Office of the Economic Adviser, «Petroleum Situation in Venezuela», Washington, 2.9.25.

US National Archives, Records of the Department of State relating to the Internal Affairs of Venezuela, 1927-1929.

US Senate (1931): «Cost of Crude Petroleum in 1931». Senate Document No. 267, 71 Cong. 3 Sess. Washington, USGPO.

- (1931a): Regulating Importation of Petroleum and Related Products. Hearings before the Committee on Commerce, 71 Cong. 3 Sess. January 29, 1931. Washington: USGPO.

— (1942): «Patents». Hearings before the Committee on Patents, 77 Cong., 2 Sess. Washington, USGPO.

- (1945): "Foreign Contracts Act». Joint Hearings before a Sub-Committee of the Committee on the Judiciary U.S. Senate and the Special Committee Investigating Petroleum Resources, 79 Cong., 1 Sess. Washington, USGPO.

- (1946): «American Petroleum Interests in Foreign Countries». Hearings before a Special Committee Investigating Petroleum Resources, 79 Cong 1 Sess. Washington, USGPO.

- (1946a): «Investigation of Petroleum Resources». Hearings before a Special Committee Investigating Petroleum Resources, 79 Cong. 1 Sess. Washington, USGPO. 
US Tariff Commission (1946): Petroleum, War Changes in Industry Series No. 17. Washington: USGPO.

- (1952): «The International Petroleum Cartel». Senate Committee Print No. 6, 82 Cong. 2 Sess. Washington, USGPO.

Venezuela, Ministerio de Minas e Hidrocarburos, Dirección General (1964): Petróleo y Otros Datos Estadísticos. Caracas, NP.

- Ministry of Mines and Hydrocarbons, Directorate General (1966): Venezuelan Petroleum Industry. Statistical Data. Caracas, NP.

\section{Author Citations}

American Petroleum Institute (1939): Petroleum Facts \& Figures. New York, API, 6th Edition.

BAptista, A. (1997): Bases Cuantitativas de la Economia Venezolana, 1830-1995. Caracas, Fundación Polar.

Bastiat, F. (1996): Economic Sophisms. Irvington-on-Hudson, New York, The Foundation for Economic Education.

Bates, J. L. (1963): The Origins of Teapot Dome. Progressive Parties and Petroleum, 19091921. Urbana: University of Illinois Press.

Bhagwati, J. (1988): Protectionism. Cambridge, Mass., MIT Press.

Blakeley, R. G., and Blakeley, G. S. (1932): «The Revenue Act of 1932». American Economic Association, 22 (4), pp. 620-640.

Bradley Jr., R. L. (1989): The Mirage of Oil Protection. Lanham, University Press of America.

BRAND, D. R. (1983): «Corporatism, the NRA and the Oil Industry». Political Science Quarterly, 98: 1 (Spring), pp. 99-118.

Brown, J. C. (1985): «Why Foreign Oil Companies Shifted their Production from Mexico to Venezuela during the 1920s». The American Historical Review, 90: 2, pp. 362385.

BUTLER, J. D. (1959): «The influence of economic factors on the location of oil refineries (with primary reference to the world outside the USA and USSR)». The Journal of Industrial Economics, 1 (3), pp. 187-201.

Carrillo Batalla, T. E. (2003): Cuentas Nacionales de Venezuela, 1915-1935. Caracas, Banco Central de Venezuela.

De Chazeau, M. G., and Kahn, A. E. (1973): Integration and Competition in the Petroleum Industry. Port Washington, New York, Kennikat Press.

Deterding, Sir H. (1934): An International Oilman. London: Ivor Nicholson \& Watson Ltd.

DunN, R. W. (1926): American Foreign Investments. New York: B W Huebsch \& The Viking Press, 1926.

Engler, R. (1961): The Politics of Oil. A Study of Private Power and Democratic Directions. New York: The MacMillan Co.

Knudson, D. L. T. (1975): «Petroleum, Venezuela and the United States, 1920-1941». PhD Diss., Michigan State University.

Larson, H. M., Knowlton, E. H., and Popple, Ch. S. (1971): History of Standard Oil Company (New Jersey). New Horizons, 1827-1950. New York, Harper Row Publishers.

McBeth, B. S. (1983): Juan Vicente Gómez and the Oil Companies in Venezuela, 19081935. Cambridge, Cambridge University Press, 1983.

- (1985): British Oil Policy, 1919-1939. London, Frank Cass \& Co. 
McDermond, C. C. (1932): Who's Who in Venezuela. Maracaibo: NP, 2 Ed.

Messerlin, P. A. (2001): Measuring the Costs of Protectionism in Europe: European Commercial Policy for the 2000s. Washington, D. C., Institute for International Economics.

Nash, G. D. (1968): The United States Oil Policy. Pittsburgh: University of Pittsburgh Press.

Noggle, B. (1965) Teapot Dome. Oil and Politics in the 1920's. New York: W W Norton \& Co. Inc.

Rangel, D. A. (1970): Capital y Desarrollo. El Rey Petróleo. Caracas: Universidad Central de Venezuela, vol. 2.

Redfield, A. H. (1942): «Our Petroleum Diplomacy in Latin America». PhD Diss., The American University (Washington).

Ricardo, D. (1992): The Works and Correspondence of David Ricardo, vol. 1, ed. Piero Sraffa \& Maurice Dobb, Cambridge, Cambridge University Press.

RIPPY, J. F. (1958): Globe \& Hemisphere. Latin America's Place in Post-War Foreign Relations of the United States. Chicago: Henry Regency \& Co.

Rostow, E. V. (1948): A National Policy of the Oil Industry. New Haven: Yale University Press.

SCHAFFER, E. H. (1968): The Oil Import Program of the United States. New York: Frederick A Praeger.

Skinner, W. R. (1936): The Oil and Petroleum Manual, London, NP.

SmiLey, G. (2002): Rethinking the Great Depression. Chicago, Ivan R Dee Publisher.

Sмiтh, A. (1981): The Wealth of Nations. Indianapolis: Liberty Fund/Liberty Press.

Uren, L. Ch. (1950): Petroleum Production Engineering. Petroleum Production Economics. New York, McGraw-Hill Book Co. Inc.

WaTKINS, M. W. (1973): Oil stabilization or conservation? A case study in the organization of industrial control. New York, Harper \& Brothers Publishers.

Williamson, H. F. et al (1963): The American Petroleum Industry. The Age of Energy, 1899-1959. Vol. 2, Evanston, Northwestern University Press. 